\title{
ODIN OG ORDET
}

Om sprog og bevidstgørelse i den norrøne mytologi

\author{
Kirsten Backhausen
}

Blandt mange ansvarsområder inden for den norrøne mytologi hersker Odin over visdom og digtning og dermed over sproget. Enhver bevidstgørelse handler om at formulere en viden og, for at kunne drage nytte af denne viden, om at kunne fastholde og videregive den til andre.

Viden og sprog forener sig i den norrøne mytologi i skjaldemjøden, og som forklaring på Odins viden og veltalenhed er det naturligt, at flere myter beskæftiger sig med, hvordan Odin kom i besiddelse af mjøden. I denne artikel vil jeg koncentrere mig om tre tekstuddrag, der omhandler Odins erhvervelse af mjøden. De første to uddrag stammer fra forskellige steder i Codex Regius-digtet Hávamál (str. 138-141 og 103-110), hvor Odin i det første uddrag som led i en initiationsrite modtager en drik af mjøden, mens det andet uddrag mere eksplicit beskæftiger sig med ranet af mjøden. Det sidste uddrag er fra Skáldskaparmál i Snorris Edda, og dette uddrag understøtter på mange måder historien om ranet, som den er fortalt i Hávamál. Tilsammen kan disse tekstuddrag sige noget om ordets magt og om, hvordan Odin udnytter denne magt til at uddele og tilbageholde viden inden for det mytiske univers.

\section{Hávamál strofe 138-141}

Stroferne 138-141 i Hávamál fungerer som et ætiologisk tilbageblik, der forklarer, hvordan Odin opnåede sit kendskab til runerne. Samtidig giver de en version af, hvordan han kom i besiddelse af skjaldemjøden. Stroferne lyder således: ${ }^{1}$

138 Jeg ved at jeg hang

i det vindomsuste træ

ni hele nætter

med spyd såret

og givet Odin

selv givet mig selv

i det træ

som ingen ved

af hvilke rødder randt.

\footnotetext{
${ }^{1}$ Ved citater på oldislandsk vil artiklen igennem følge Neckel \& Kuhn 1962. Oversættelserne er mine.
} 
139 Brød gav de mig ikke

de bragte ikke horn

jeg så ned

jeg tog runer op

skrigende tog jeg

og faldt så ned derfra.

140 Ni store sange

fik jeg af den berømte søn

af Bølthorn, Bestlas far

og en drik jeg fik

af den dyrebare mjød

øst af Odrørir.

141 Da blev jeg frodig

og kundskabsrig

og voksede og trivedes vel

ord mig fra ord

til ord førte

værk mig fra værk

til værk førte.

Det er blevet diskuteret, om hængningen skal ses som en ofring eller som en initiation (se f.eks. Schjødt 1995; Ross 1994). Selvhængningen rummer elementer af begge strukturer, både ofring og initiation, i sig. Dog finder jeg, at den på grund af Odins store trivsel bagefter ligger tættest på initiationen, hvorfor stroferne i det følgende først og fremmest vil blive læst som en initiationsrite (jf. Backhausen 1999). Odin befinder sig i stroferne i en marginaltilstand mellem liv og død. En initiation kan ses som en symbolsk ofring med en tilhørende symbolsk død, hvorfra man genopstår i en ny og beriget tilstand. En del af initianden er efterladt i døden, og han/hun genopstår i transformeret tilstand. Sammen med dødssymbolikken indeholder initiationen dermed også en udviklet fødselssymbolik. Efter de ni nætter i træet genfødes Odin til ny og større viden. Han har opnået runernes hemmelighedsfulde visdom. Samtidig bringer han selv med et skrig runevisdommen ind i verden. Herved har vi en fødsel på to planer. Odin kan siges at føde runevisdommen ind i denne verden, men genfødes samtidig selv af træet.

Når vi hører om en hængning, antager vi som regel straks, at den hængte hænger i en løkke om halsen. De fire aktuelle strofer siger intet herom. Men hvis runerne, opfattet som en fysisk størrelse, der skal gribes, for at de kan begribes på det mentale plan, skal samles op, mens Odin hænger i træet, er det ikke muligt, hvis Odin hænger ved halsen. $\mathrm{Nu}$ er fysiske umuligheder sjældent noget, myterne tager så højtideligt, men alligevel finder jeg det på sin plads at overveje den løsning, som Jere Fleck har foreslået, nemlig at der er tale om en inverteret hængning (Fleck 1971).

For at den hemmelighedsfulde viden i form af runer kan hentes i underverdenen, må Odin gennem en initiationsrite nærme sig døden, som hører til i underverdenen. Inversi- 
on symboliserer ofte både død og genfødsel og har forbindelse til underverdenen, idet man i den folkelige forestilling har associeret underverdenen med et sted, hvor alting er vendt på hovedet. ${ }^{2}$ At blive placeret med hovedet nedad er derfor at blive anbragt i samme position som de døde, og inversionen af en initiand er derfor identisk med den rituelle død (Fleck 1971). Hvis Odin hænger med hovedet nedad, samler runerne op og derefter falder ned fra træet, så sker faldet med hovedet først. Det kan sammenstilles med en fødsel, som også i de fleste tilfælde sker med hovedet først. Faldet markerer dermed fuldbyrdelsen af initiationen og genfødslen til det nye liv på et højere vidensplan.

I strofe 140 får Odin en drik af den dyrebare mjød, Odrørir. Den første del af navnet Óðrørir kommer af óðr, som for det første kan betyde 'sjæl’, 'forstand' eller ‘digterevne'. Men brugt adjektivisk har det endnu en betydning, nemlig 'rasende' eller 'voldsom' (Lexicon Poeticum 1966). Det er den samme rod som i navnet Odin (Óðinn), hvilket da også bl.a. af Adam af Bremen er blevet oversat med den adjektiviske betydning af óðr, idet han i forbindelse med beskrivelsen af de tre gudestøtter i helligdommen i Uppsala skriver: “Wodan, id est furor”: Odin, det er raseri (Adam af Bremen 1978, 48f). Óðr kan også benyttes i sammenhængen “drekka sic óðan”, med betydningen "at drikke sig rasende fuld” (Lexicon Poeticum 1966). Et rasende fuldt menneske virker ikke særlig poetisk, men i overført forstand kan rusen bruges til at sige noget om andre former for raseri, hvilket f.eks. kunne være ekstasen. Alkohol kan sætte sindet i bevægelse med en ekstaselignende tilstand til følge. Den ekstatiske tilstand generelt må derfor også symbolsk kunne beskrives gennem beruselse.

Sindet sættes i bevægelse af rusen, og selvom rusen her forbindes med en drik, kan den i forbindelse med ekstasen også ses som en intellektuel rus, en åndelig beruselse af viden. ${ }^{3}$ Rusens ekstase kendetegnes bl.a. ved, at man ser anderledes på verden og bevæger sig anderledes i den. Den ekstase, man kan opnå via en pludseligt forøget åndelig indsigt eller viden, må på samme måde påvirke den måde, man forholder sig til sine omgivelser på. En rus er også opløftende og giver - samtidig med en svævende fornemmelse - et indtryk af at se det hele 'lidt fra oven'. Forskellen på den fysiske og den intellektuelle rus kan have noget at gøre med den klarhed, man opfatter det sete med. Den fysiske rus giver et illusorisk greb om verden. Den på det overførte plan berusende viden både skaber og skabes af et reelt overblik i den nye tilgang til verden.

Odrørir er selve skjaldemjøden, der genererer ord. Dermed bliver det først og fremmest ordet, der har den berusende virkning. Denne virkning medfører i den efterfølgende strofe (141), at Odin bliver frodig, vokser og trives ("Pá nam ec frœvaz / oc fróðr

\footnotetext{
${ }^{2}$ Vries 1970, 287: “... das Anblicken einer Welt, die das Obere und das Untere vertauscht hat, gehören zu den gewöhnlichen Vorstellungen der Totenwelt.”

${ }^{3}$ John Stephens (1972) siger om sammenhængen mellem poetisk og alkoholrelateret beruselse, at når Odin i Hávamál drikker mjøden, kan han siges at drikke sproget. I forbindelse med Snorris myte om mjøden spytter han det ud igen, hvoraf Stephens udleder: "It is at this point that the analogy between poetic and drunken intoxication manifests itself. Something consumed which subsequently produces both rapture and vomiting must be an intoxicating drink".
} 
vera / oc vaxa oc vel hafaz”). Fræevaz betyder 'at sætte frø' eller 'at blive frugtbar', mens fróðr betyder 'kyndig' eller 'kundskabsrig', især om den, der har erhvervede, tillærte kundskaber (Lexicon Poeticum 1966). Odin har nu erhvervet nogle kundskaber fra underverdenen - kundskaber, som i og med at de er tillærte også til en vis grad må være kulturelle, eller i hvert fald bliver gjort kulturelle i læreprocessen. Denne viden sætter frø, den udvikles og vokser, og dette sker $i$ Odin. Dermed kan han tillægges den kvindelige egenskab at være frugtbar, at kunne give liv, men den livgivende funktion er på det åndelige og vidensmæssige plan. Den frugtbare beruselse af viden, Odin opnår gennem mjøden, følges på vej af runerne. Runerne kan fastholde det intellektuelle råmateriale, der hentes i underverdenen. Det samme gælder de ni sange, som Odin får ved samme lejlighed. Den faste metriske form på disse sange kan fastholde de enkelte formuleringer ordret, og dermed fastholdes også deres indhold og magiske kraft i deres oprindelige form. Den stramme opbygning gør dem derfor til et velegnet medie til fastholdelse og udøvelse af numinøs viden.

De sidste 18 strofer (146-163) før den afsluttende strofe i det store digt, Hávamál, omhandler 18 tryllesange, som Odin kender, men ikke uden videre vil afsløre. Han fortæller om deres virkning, men selve sangene holder han for sig selv. Disse tryllesange kan have en forbindelse til de ni sange, Odin modtager sammen med mjøden efter sin hængning. ${ }^{4}$ Tallet ni henviser i mytologien til noget komplet, og de ni sange, Odin modtager, rummer dermed en afrundet helhed af viden og kundskab, hvor ud af de 18 sange senere kan hentes. ${ }^{5}$

Både mjøden og sangene kan siges at være åndelig næring, idet de får Odin til at trives. For at kunne vokse på det fysiske plan kræves fysisk næring. Det samme gælder på det overførte plan for åndelig vækst. Væksten sker ikke af sig selv, men begynder med en ydre påvirkning, som sætter en proces i gang. Odins vækstproces sættes i første omgang i gang af den pinefulde rite, men fortsættes derefter i lidt mere konkret forstand af udbyttet af riten, nemlig mjøden og sangene.

Som den højeste gud har Odin i sig selv en vis overlegenhed, men han udvikler denne ved at gennemgå en rituel uddannelse via hængningen. For at kunne leve op til den afbalancerende funktion, han tildeles i det mytiske kosmos, er han hele tiden nødt til at udvide sin viden og sin evne til at bemestre denne. Da Odin indvies af Bølthorns søn, som er jætte, er den viden, han opnår, oprindeligt associeret med jætterne, der var de første levende, antropomorfe væsner (Vafðrúðnismál str. 29). Odin får dermed adgang til en viden fra langt før verdens og kosmos’ skabelse, og i kraft af denne viden om fortiden får han indsigt i verdens gang på en måde, som sætter ham bedre i stand til at varetage sin afbalancerende funktion i nutiden og fremtiden.

\footnotetext{
${ }^{4}$ See 1972, 5: “ $\ldots$ da 138-163 davon handeln, wie Odin bei seinem Selbstopfer mit Hilfe der Runen Weisheit und magische Fähigkeiten erwirbt, wobei in 146-163 Anwendung und Wirkung von achtzehn verschiedenen Zauberliedern ... durchnummeriert werden.” Boer (u. år), 47: "Bugge ... setzt sehr scharfsinnig die 18 sprüche (147ff) mit 140,1. 141 in verbindung."

${ }^{5}$ For helhedsaspektet af tallet 9, se f.eks. Schjødt 1988, 38, samt Ross 1994, 51.
} 
Den viden, Odin opnår, kan han formidle og gøre alment tilgængelig i denne verden. Men gennem sine tilbageholdte tryllesange gemmer han et uovertruffent våben til sig selv og opretholder dermed sin overlegenhed i forhold til de andre figurer i det mytiske univers. Ved hjælp af sangenes kraft har han en unik mulighed for at påvirke verden. Og dog er det ikke nok til at afværge den katastrofe, der hele tiden lurer ude i fremtiden i form af det uafvendelige Ragnarok.

\section{Hávamál strofe 103-110}

Myten om Odins hængning tilbyder én forklaring på, hvordan Odin blev sat i forbindelse med skjaldemjøden. Men andetsteds i Hávamál gives en anden forklaring.

103 En glad mand hjemme og mod gæsten munter og smidig af sind skal man være med erindring og snaksalighed hvis han meget klog vil være om godt skal han ofte tale stor tåbe

skal han hedde, som kun kan tale lidt

det er den ukloges væsen.

104 Den gamle jætte jeg søgte er nu igen tilbage kun lidt fik jeg tiende der mange ord talte jeg til min fordel i Suttungs sale.

105 Gunlød gav mig på den gyldne stol en drik af den dyrebare mjød ond gengæld lod jeg hende derefter få for hele hendes tanke for hendes tunge sind.

106 Ratis mund lod jeg rydde mig vej og gnave i sten over og under gik jætters veje således udsatte jeg mit hoved for fare.

107 Vel købt ydre har jeg vel nydt den kloge mangler kun lidt for Odrørir er nu kommet op på gammel helligdoms grund.

108 Jeg tvivler på at jeg var kommet tilbage ud af jætternes hjem hvis jeg ikke udnyttede Gunlød denne gode kvinde hun, som lagde sin arm om mig.

109 Dagen efter gik Rimturserne ved den Højes Råd at spørge i den Højes hal de spurgte efter Bølverk om han var kommet til guderne eller var han dræbt af Suttung.

110 Odin en ring-ed tror jeg har sværget hvem vil tro hans ord? Suttung har han bedraget for hans drik og voldt Gunløds gråd.

Odins forførelse af Gunlød er det tema, som kommer først i Hávamáls beretning om skjaldemjøden. De aktuelle strofer befinder sig i Hávamál i umiddelbar forlængelse af en anden forførelseshistorie med modsat fortegn. I strofe 96-102 er det Odin, der længes 
efter Billings mø, men hun holder ham for nar, og hans forsøg på forførelse mødes kun med hån. I stroferne 103-110 er det derimod kvinden Gunlød, der er forelsket og lader sig forføre af Odin, og derefter Odin, der holder hende for nar. Ved hjælp af sine mange flotte ord får han fordrejet hovedet på kvinden og kan derefter bruge hende som redskab til at få fat på den mjød, som er det vigtigste tema i myten. Gunlød omtales i stroferne her ikke direkte som vogter af mjøden, som hun gør hos Snorri, men da Odin først ved hjælp af sin glatte tale er kommet inden for hos jætterne, er det stadig hende, som giver ham en drik af mjøden. Hun er altså et vigtigt forbindelsesled for Odin, hvis han skal have mjøden.

Når Odin kan opnå det kortvarige og gunstige forhold til Gunlød via ord, så er det altså ikke udelukkende med talekunsten for øje, at Odin er ude efter mjøden. Odin kan allerede formulere sig. Mjøden må derfor også rumme andre vigtige egenskaber, som er væsentlige for Odin at få fat på. Mjød er en gæret væske med en berusende effekt. Men simpel beruselse er heller ikke det, som Odin primært ønsker at opnå. Andetsteds i Hávamál advares der direkte mod beruselse (str. 11-15). Her henvises også kort til myten om skjaldemjøden (str. 13), hvor rusen siges at stjæle forstanden og bringe glemsel, en glemsel, som holdt Odin fangen i Gunløds gård. I disse løsrevne strofer beskrives Odin som påvirket af den berusende drik, mens han er hos Gunlød, hvilket står i modsætning til den Odin, vi møder i strofe 103-110. Her er han klar i hovedet og meget beregnende.

Noget kunne tyde på, at der er tale om to forskellige slags rus. Der er den glemselsrus, som i strofe 11-14 fratager enhver drukkenbolt forstanden. Men der findes også en rus på et overført plan. En rus $i$ forstanden, en udvidelse af intellektet, der kan give en berusende fornemmelse. Her nærmer vi os den rus, vi også så i strofe 138-141 omkring hængningen. I strofe 103-110 er rusen tættest knyttet til den intellektuelle og sproglige rus fra strofe 138-141, hvilket også forklarer, hvorfor det er vigtigt for Odin at få fat i mjøden. Han udsætter sig for fare for at erhverve den. Det ville man næppe gøre for en simpel rus, men snarere for den intellektuelle rus, der kan være med til at sætte én i stand til at håndtere livet og verden.

Målet for Odin i de aktuelle strofer er at erhverve mjøden, og da Gunlød råder over den, må Odin gå gennem hende. Det gør han via en forførelse, og dermed kommer hans maskuline sider til at spille en stor rolle. På overfladeplanet vises det først og fremmest ved hentydningerne til, at Odin skulle have givet Gunlød løfte om ægteskab (str. 110), men også på symbolplanet understreges den aggressive maskuline tilgang til sagen. Penetrationen af bjerget er en del af den maskuline aktivitet, der ofte fremhæves i modsætning til en feminin passivitet, og aktiviteten passer også godt sammen med den aktive rolle, Odin i det hele taget spiller i forførelsen af Gunlød.

\section{Skáldskaparmál}

Fortællingen om skjaldemjøden i Hávamál er ikke særlig udbygget, men fungerer først og fremmest via allusioner til en bagvedliggende myte. Hvis man ikke kender lidt til myten i forvejen, er det svært at forstå, hvad stroferne egentlig siger. Samtidig er er- 
hvervelsen af mjøden skubbet i baggrunden til fordel for en anden historie, der handler om forholdet mellem mænd og kvinder og her i særdeleshed om, hvordan en mand kan forføre en kvinde for egen vindings skyld.

I Skáldskaparmál i Snorris Edda, den afdeling, hvor han behandler det poetiske sprog og dets kenninger, fortælles myten om skjaldemjøden til illustration af kenninger om digtekunst (Snorri Sturluson Edda 1926, 71-74). Fortællingen er bygget op omkring Ægir, som besøger guderne i Asgård og der sidder ved siden af Brage, hvem han stiller mange spørgsmål. Et af spørgsmålene går på, hvordan poesien opstod. Som svar fortæller Brage en lang historie, som falder i tre dele. Begyndelsen ligger helt tilbage ved asevane krigen. Ved fredsslutningen mellem de to parter spytter begge parter i et kar, og ud af spyttet skaber aserne en mand ved navn Kvasir. Kvasir er så klog, at han kan svare på alle spørgsmål, og han rejser rundt i verden og bibringer kundskab. Da han kommer til dværgene Fjalar og Galar, dræber de ham og fylder hans blod i tre kar ved navnene Odrørir, Son og Bodn. Blodet blander de med honning og laver det til skjalde- og visdomsmjød. Til aserne forklarer Fjalar og Galar, at Kvasir er blevet kvalt i sin egen kundskab.

Næste afsnit handler om, hvordan mjøden kom i jætternes varetægt. Jætten Gilling og hans kone besøger dværgene. De dræber først Gilling ved at lade ham drukne, og derefter slår de Gillings højlydt sørgende kone ihjel med en møllesten. Da Gillings søn, Suttung, finder ud af dette, anbringer han dværgene på et skær, som oversvømmes ved højvande. For at blive reddet tilbyder dværgene skjaldemjøden til Suttung, og han bringer den med sig hjem og lader sin datter Gunlød vogte over den.

Den sidste del af fortællingen handler om, hvordan aserne fik fat i mjøden. Odin drager ud og møder ni trælle, der slår hø. Han tilbyder at slibe deres leer, og han gør det så godt, at de alle gerne vil købe hans slibesten. Odin kaster stenen op i luften, og alle slaverne griber efter den med det resultat, at de hugger hovederne af hinanden med deres leer. Odin går da under navnet Bølverk til slavernes ejer Baugi, som er bror til Suttung, og tilbyder at arbejde for ni mand. Som løn betinger han sig en drik af Suttungs mjød. Det kan Baugi ikke love, man han lover i stedet at gå med Odin og forsøge at få fat på mjøden. Da de begge kommer til Suttung og beder om mjøden, afvises de. Odin giver nu boret 'Rati' til Baugi og beder ham bore et hul i bjerget. Da Baugi første gang siger, at hullet er boret, puster Odin deri, og da spånerne flyver ud i hovedet på ham selv, ved han, at Baugi forsøger at snyde ham. Han beordrer Baugi til at bore resten af vejen igennem, og da spånerne blæses indad, skaber Odin sig om til en orm og kryber igennem hullet. Baugi forsøger at ramme ham med boret, men rammer ikke. Odin kommer nu ind til Gunlød, Suttungs datter, som vogter mjøden, og han sover med hende i tre nætter. For hver nat får Odin lov til at drikke en slurk af mjøden, og for hver slurk tømmer Odin et af de tre kar. Derefter skaber han sig om til en ørn og flyver væk. Suttung forfølger ham, også i ørneham. Aserne ser dem komme og sætter nogle beholdere ud i gården, hvori Odin kan spytte mjøden ud. Men Suttung er så tæt på at fange ham, at han også sender lidt mjød bagud, hvilket er skáldfífla hlut, de dårlige skjaldes del. Resten af mjøden giver Odin til aser og skjalde. 
Forførelsen spiller hos Snorri langt fra den rolle, som den gør i Hávamál. Men det betyder ikke, at seksualsymbolikken er fraværende, tværtimod. Hvor Odin i Hávamál borede sig vej ud af bjerget, går bevægelsen i denne udgave indad i bjerget, hvilket giver endnu tydeligere allusioner til den maskuline penetration af det hule bjerg. Selve den handling at forføre Gunlød spiller ingen rolle her. Det konstateres blot, at Odin lå tre nætter ved Gunlød, og at hun derefter gav ham lov til at drikke af mjøden. På trods af den maskuline handlekraft, Odin demonstrerer ved at gennemtrænge bjerget i form af en orm, kan han dog ikke erhverve mjøden uden hjælp fra en kvinde.

En anden forskel, der kan nævnes mellem de to kilder, er, at navnet Odrørir tilsyneladende i Hávamál er navnet på selve mjøden, mens det hos Snorri er reduceret til navnet på et af de tre kar, mjøden opbevares i. Derudover er den dårlige del af mjøden (skáldfífla hlut, de dårlige skjaldes andel), som Odin sender bagud under flugten, muligvis blot et sjovt påfund fra Snorris side, der fængede hos hans samtidige og dermed udviklede sig til en række kenninger (Frank 1981, 168).

Snorris fortælling om mjøden falder som vist i tre dele. Undervejs gennemgår mjøden forskellige transformationer, som hver især føjer et ekstra lag af betydning til mjøden. I første del startes processen med kropsvæsker, nemlig spyt fra henholdsvis aser og vaner. Spyt brugtes som igangsætter af en gæringsproces, og allerede her undfanges mjøden altså. Den tager sin begyndelse sammen med det ordnede samfunds begyndelse (Schjødt 1983, 9), og da aserne gerne vil bevare dette tegn på fred mellem de to dominerende grupper i samfundet, skaber de væsken om til en mand ved navn Kvasir. Navnet hentyder igen til en berusende væske, idet betydningen formodentlig er noget i retning af kvast frugt, hvilket ofte dannede basis for gærede drikke (Frank 1981, 159). Kvasir er overordentlig vis - så vis, at han ifølge dværgene kvæles i sin egen visdom. Da ingen formår at stille spørgsmål, der kan forløse noget af visdommen, bliver det for meget at rumme for en enkelt person, og han må dø for at kunne transformeres til en mere anvendelig form for visdom eller kundskab. At det er dværge, der udfører denne første transformationshandling, rummer vigtige pointer. De er ktoniske væsener, hvilket vil sige, at de er knyttet til underverdenen, der næsten altid spiller en rolle i transformationsprocesser. Samtidig er dværgene som dygtige håndværkere mestre for mange af de meget nyttige redskaber, aserne besidder, f.eks. Thors hammer Mjølner, Freys skib Skidbladner, og Odins spyd Gungner (Snorri Sturluson Edda 1926, 97f). I den aktuelle tekst blander dværgene Kvasirs blod med honning og producerer dermed den mjød, som senere også bliver et vigtigt intellektuelt redskab for aserne, herunder Odin.

Kvasir er et produkt af fredsslutningen mellem aser og vaner, en fredsslutning, der kan læses som samfundets opståen. ${ }^{6}$ Han er dermed i høj grad et kulturprodukt, hvilket også understreges af hans overordentlige visdom, som dog endnu ikke findes i en håndterlig form, og som dermed heller ikke kan komme til nytte. I form af Kvasirs blod findes visdommen nu som en konkret og koncentreret substans, som kan gøres til genstand for behandling.

\footnotetext{
${ }^{6}$ Schjødt 1983, 89: “næsten alle nyere forskere er enige om at anskue fredsslutningen mellem dem [aser og vaner] som selve det mytiske udtryk for oprettelsen af samfundet.”
} 
Fra de ktoniske dværge kommer mjøden i jætternes varetægt og føres nu endnu længere ned i underverdenen. For det første derved, at den anbringes dybt inde i et bjerg og altså i bogstaveligste forstand befinder sig under jorden. For det andet derved, at den bevogtes af en kvinde. Det underjordiske knytter sig tæt til døden, da de døde næsten altid placeres under jorden. ${ }^{7}$ Viden fra den anden verden lægger sig også til begge disse kategorier, idet den ofte opnås gennem rejser til underverdenen og/eller gennem kontakt med døde eller komatøse vølver. Gennem vølverne knyttes dermed også feminiteten som semantisk kategori til den anden verden (Schjødt 1983, 94f). Anbragt under jorden i en kvindes varetægt befinder mjøden sig altså på dette stadium i den anden verden. Samtidig kan bjerget ses som et udtryk for axis mundi, verdensaksen, og dermed som en parallel til Yggdrasil i myten om Odins hængning (Schjødt 1983, 92). Verdensaksen skaber en forbindelse mellem de forskellige stokværk i verden og dermed også mellem de forskellige niveauer af viden. Gunlød sidder dybt inde i bjerget og er dermed et bindeled i forhold til den dybeste og inderste viden fra den anden verden. Denne viden må Odin begive sig til underverdenen for at hente.

Først her når vi frem til de handlingselementer, vi også finder i Hávamál. Efter at mjøden har bevæget sig hele vejen ned til underverdenen, er tiden nu kommet for Odin til at hente den op igen og bringe den til aktivt virke. Efter at have arbejdet for Suttungs bror i et stykke tid, forsøger Odin først at tale sig til mjøden, som vi også så det ske i Hávamál. Denne fremgangsmåde lykkes imidlertid ikke, og Odin må i form af en orm bore sig vej gennem bjerget for at nå frem til mjøden. Han må altså med en aktiv fysisk handling tiltvinge sig adgang til den anden verden inde i bjerget. Gennem den falliske symbolik, der ligger både i boret og i ormehammen, kan man sige, at Odin her benytter sig af sin maskulinitet. Han fortsætter ad dette spor, da han når ind til Gunlød og opnår adgang til mjøden ved at sove med hende. Han er altså meget direkte i kontakt med alle de førnævnte kategorier: underverdenen, døden og ikke mindst det feminine.

Da Odin er kommet i besiddelse af mjøden, skaber han sig om til en ørn og flyver bort med drikken. Han løfter den fra verdensaksens underjordiske stokværk til det himmelske, fra jorden til luften, og bringer den til Asgård. Her spyttes mjøden ud i nogle kar, der er stillet parat til formålet. Vi både begynder og ender altså med en væske, der spyttes ud af munden, men undervejs i transformationerne har væsken fået tilføjet flere betydningslag. De første spytdråber var en fredspagt i forbindelse med samfundets opståen. De sidste er en fuldt færdig skjaldemjød, der efter at have været hele vejen omkring det feminine og den anden verden nu er parat til et aktivt virke.

\section{Fra underverden til oververden}

De tre tekstuddrag omhandler alle det samme mytiske kernestof omkring mjød og visdom, og alene redundansen antyder, at temaet er vigtigt. Mjød og visdom hentes i underverdenen, og genfødes i overført betydning i oververdenen, enten derved at Odin

\footnotetext{
${ }^{7}$ Her ses bort fra Valhal-forestillingen, der af nogen regnes for at være af nyere dato (se f.eks. Roesdahl 1983). På trods af at være et sted, hvor de døde krigere kommer, præges Valhal også i høj grad af liv, da de faldne einherjer hver dag rejser sig igen. Det underjordiske dødsrige ses i Hel, og vølven, der vækkes af koma øst for Hels dør i Baldrs draumar.
} 
gennemgår en initiation og dermed selv genfødes, eller derved at han genføder mjøden symbolsk gennem munden. Bevægelsen mellem de to niveauer af verden kommer dermed flere gange i fokus.

I stroferne om Odins hængning ses en tydelig vertikal akse, som bevægelserne i forbindelse med riten alle forholder sig til. Vi begynder oppe i træet, hvor Odin hænger frit svævende. Så retter han øjet ned, tager runerne op, falder selv ned, og begynder så i strofe 141 at vokse og trives, det vil sige, at han igen begynder en spirende bevægelse opad. Yggdrasil, der i egenskab af et kosmisk træ forbinder verdens stokværk, udgør den vertikale akse, bevægelserne foregår i forhold til. Hele det mytologiske univers udgår på det horisontale plan i koncentriske cirkler herfra, og Yggdrasil er dermed centrum i dette univers. Indvielsen til noget så basalt som runernes kraft og runevisdommens hemmeligheder kan kun foregå på et sted ladet med kraft som netop her.

Den viden, der eksisterer i underverdenen, er der ikke sat ord på. Den er uhåndterlig i den form, den har. Bevidsthed om ting opstår først i det øjeblik, de kan beskrives og fastholdes med ord. De skal op i bevidstheden for at blive en del af en brugbar viden. Først i det øjeblik, Odin får adgang til denne viden og kan sætte ord på den, bliver den tilgængelig. Den hemmelighedsfulde viden, Odin henter i form af runerne, og som han magter at formulere igennem skjaldemjøden Odrørir, hentes altså op fra et ubevidst plan og gøres gennem formuleringen bevidst. Den gennemgående vertikale akse ekspliciterer dette tema. Op forbindes generelt med bevidsthed og ned med manglende bevidsthed, hvilket man kan se af de mange daglige talemåder, vi bruger. Vi står op, vågner op, mens vi falder i søvn, synker ned i koma, er under hypnose (Lakoff \& Johnson 1980). Til disse eksempler kan jeg tilføje, at noget går op for os, eller vi kan have en stigende erkendelse af noget, mens vores opmærksomhed kan dale. I strofe 140 får Odin en drik af den dyrebare mjød. Hvis der skal sættes ord på viden, før den bliver bevidst, er dette af stor betydning, idet Odin sammen med en stor viden gennem mjøden også får tildelt en evne eller et redskab til at håndtere og formidle denne viden og dermed drage nytte af den.

Også i myten om skjaldemjøden genfinder vi den vertikale akse, men ikke nær så entydigt fikseret til ét sted, som den er fikseret til træet i forbindelse med hængningen. Bjerget udgør aksen i det rum, der tegnes, men bevægelsernes retning defineres ikke udelukkende i forhold til bjerget; de forholder sig i lige så høj grad til betydningsmæssige kategorier med større eller mindre tilknytning til underverdenen. Hos Snorri går bevægelserne det første lange stykke tid kun nedad mod underverdenen. Mjøden bevæger sig fra oververdenens aser til de ktoniske dværge og derfra med en jættekvinde ind i bjerget. Efter mjøden følger Odin i samme retning. Først ved at sætte sig i kontakt med en jætte, Baugi, som han arbejder for. Derefter ved at bore sig ind i bjerget. Og sidst, men ikke mindst, ved at indgå et forhold til den selvsamme jættekvinde. Kontakten til den feminint valoriserede underverden er altså total. Først derefter går bevægelsen opad igen, idet Odin omskaber sig til en ørn og flyver bort med mjøden og altså bevæger sig fra verdens underste stokværk ved bjergets rod til det øverste stokværk over bjergets tinde. Bevægelsen er ikke helt så tydelig i Hávamál str. 103-110. Her borer Odin sig ud af bjerget i stedet for ind i det, men det har ikke den store betydning i denne sammen- 
hæng. Han har stadig været i kontakt med både jætter og ikke mindst en jættekvinde. Kun ét sted i teksten markeres retningen eksplicit, nemlig i strofe 107, hvor det siges, at Odrørir nu er kommet op til guderne.

Både mjøden og runerne, som Odin henter, er givet en konkret form. De viser begge tilbage til en uartikuleret viden, der stammer fra underverdenen, og som gennem den konkrete form kan håndteres og bringes til anvendelse i denne verden. Mjøden er i Hávamál strofe 103-110 og hos Snorri det begærede objekt. I sin konkrete form som en rusdrik har den en berusende virkning, men beruselsen knytter sig så nært til den visdom, som også ligger i mjøden, at beruselsen først og fremmest fører til en højere bevidsthedstilstand. Gennem mjøden tilføres visdom og magiske evner, så modtageren opnår en intellektuel rus, der nærmer sig ekstase. Gæringens boblende energi rummer et stort element af bevægelse. Herigennem bliver rusen et udtryk for dynamik og igangværende processer.

I forbindelse med hængningen er mjøden en ekstra gevinst oven i runerne, men ekstragevinsten er bestemt ikke betydningsløs, idet den sætter Odin i stand til at formulere den visdom, han har opnået gennem initiationen. Efter at have gennemgået lidelserne på træet kan Odin påbegynde en ny og mere fuldendt eksistensform, hvor han har magten til at transformere passiv kraft i underverdenen til en brugbar, sprogliggjort viden. Ordet kommer før værket: “orð mér af orði / orðz leitaði, / verc mér af verki / vercs leitaði” (ord blev til ord og avled nye, og værk blev til værk og virked nye). Det vil sige, at ordet til en vis grad er en forudsætning for værket. At kunne sætte ord på sin viden er en forudsætning for at kunne bruge den bevidst som et redskab i sin omgang med verden. Samtidig er det nødvendigt at kunne beskrive den verden, man ønsker at påvirke på baggrund af sin viden. Idet ord leder til ord, kan formuleringer om den eksisterende virkelighed udvikles til formuleringer om den virkelighed, der ønskes opnået. Dermed kan værket og handlingerne sættes målrettet i gang.

Det er ordet, der bryder barrieren mellem de to niveauer i verden. Det er gennem ordet, at bevidstheden opstår. Og via bevidstgørelsen gennem ordet opstår også muligheden for at handle. 
Bevægelsen kan illustreres således:

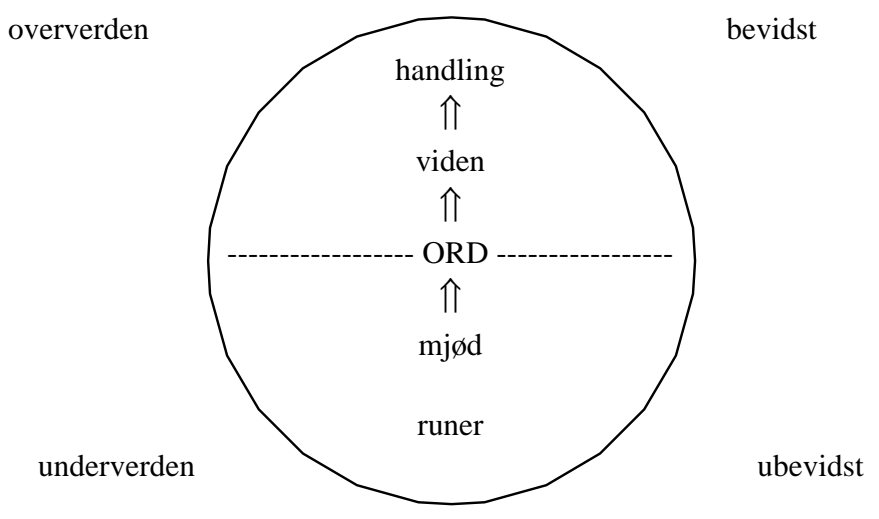

Gennem rusen og ekstasen nærmer mjøden sig det magiske. Også runerne har magisk betydning. De er en række passive tegn, som rummer en kolossal viden, men en viden som først skal omsættes, før den kan tages i brug. Ordet rune kommer nemlig af ordet rún, som både henviser til skrifttegnene som sådan, men også til hemmelighedsfuld visdom. Med runerne i hånden får Odin en enorm magt både i kraft af den viden, runerne står for på det overførte plan, men også i kraft af den begyndende skriftlighed, runerne markerer. Idet Odin ejer disse tegn, kan han begynde at fastholde viden, en evne som utvivlsomt må afføde respekt i et mundtligt samfund, hvor erindringen er af stor vigtighed. Erindringens betydning ses blandt andet i Grímnismál str. 20, hvor Odin ængstes for Huginn, tanken, men dog endnu mere for Muninn, hukommelsen. Hverken tanke eller hukommelse nedprioriteres med runeskriften, men ved at besidde tegn, som kun meget få kan forstå og som kan fungere til videregivelse af viden, også over lange afstande enten geografisk eller i tid, får man ganske givet en særlig status i et ellers mundtligt samfund. Ikke mindst fordi det at kunne få en mening ud af tegnene sandsynligvis har virket magisk på de folk, der ikke forstod dem. Runerne tillægges dermed en stor kraft og bliver nært forbundet med det magiske:

Eine Kunst, die nur von wenigen gekannt und geübt wurde, war schon deshalb für das gewöhnliche Volk Gegenstand der Ehrfurcht und des Staunens. Segen- und Fluchformeln, die ausgesprochen schon so weitgehende Wirkung haben konnten, bekamen eine noch viel grö_ere Kraft, sobald sie in einem Stab eingeritzt wurden und dadurch für eine fast unbegrenzte Zeit ihre Wirkung ausüben konnten. (Vries 1970, 308)

Runernes vigtigste egenskab er altså evnen til fastholdelse, hvor mjøden i højere grad har at gøre med formuleringen af den opnåede viden. Men i dem begge ligger der en stor magisk kraft.

Tryllesangene er et komprimeret sprog med en aktiv og direkte virkning på verden. Odin får ni sange ved sin initiation og fortæller i de efterfølgende strofer, at han kender 
endnu 18 (Hávamál, str. 140 og 146-163). De fleste af de 18 sange har en ret konkret og afgrænset virkning, som beskrives, men selve sangene afsløres ikke. Virkningen af sangene spænder vidt, lige fra helbredende virkning (str.147) over evner, der kan hjælpe i kamp ved f.eks. at standse en fjendtlig pil med synet (str. 150), til magt over elementerne ild, vind og vand (str. 152 og 154). Også kærligheden har sangene magt over (str.161-162) og ikke mindst, som tidligere nævnt, over døden, idet Odin med sine galdrer (tryllesange) kan vække de hængte og tale med dem (str.157). At kende disse sange giver altså magt over verden, og giver dermed udøveren et forspring for skæbnen. Flere af tryllesangene kan i høj grad virke ønskeopfyldende, som det at skabe sig en fordel i kampen, og ikke mindst det at kunne fremkalde kærlighed hos den elskede. Magien nedbryder skellet mellem det ønskede og det mulige og gør ønske til handling. Sangens ord flytter energien i ønsket fra det passive til det aktive og bringer dermed kræfter fra underverdenen op til oververdenen.

\section{Odin og ordet}

For at kunne fungere som kanal må ordet rodfæstes. Som den, der drager ord og viden op fra underverdenen, bliver Odin også den, der må varetage denne funktion. Dette sker to steder: Ordet forankres i den hemmelige sang, som Odin ender sin opremsning med i Hávamál, og det forankres i de hemmelige ord, som Odin hvisker Baldr i øret i Vafðrúðnismál, før han bliver lagt på bålet.

Den attende sang i Hávamál (str. 163) vil Odin ikke afsløre noget om, ikke engang hvad dens virkning er. Den eneste, som måske kan have adgang til sangen, er Frigg, Odins kone. Odin har ingen søster, og kan derfor roligt love at fortælle til en sådan. Det er dog værd at bemærke, at der i strofen er stor fokus på kvinder. Han vil ikke berette til mø eller mands kone, men måske til egen kone eller søster. Den viden, sangen rummer, er altså på en eller anden måde knyttet til det feminine. Men vi har tydeligvis at gøre med en dyb hemmelighed, som helst skal forblive en sådan: “alt er betra, / er einn um kann”, alt er bedst, som kun én ved. Et forslag til, hvad hemmeligheden kunne være, er, hvad Odin hviskede Baldr i øret, før han blev lagt på bålet (Jónsson 1924, 167; Evans 1986, 143). Denne hvisken er en af de allerstørste hemmeligheder inden for den norrøne mytologi, men for mig at se kan strofen i Hávamál lige så godt handle om selve begrebet hemmelighed som sådan. Det er selve det, at Odin har en viden, som ingen anden har, der er i fokus. Hemmeligheden knytter sig til underverdenen, idet den i kraft af sin status som hemmelig er passiv, og den forbindes i strofen med det feminine.

Uanset om den hemmelige sang og Odins ord til Baldr er det samme, så er der i hvert fald den sammenhæng, at ordene i de to situationer er lige ukendte for alle andre end Odin. I Vafðrúðnismál vinder Odin en videnskonkurrence ved at spørge om, hvad det var, han hviskede sin søn i øret. De ord, Odin hviskede til Baldr, forsvinder eller gøres utilgængelige, idet de med Baldr når underverdenen. Kun Odin kender til dem, og derfor har også kun han adgang til at hente dem. Men denne adgang eksisterer til stadighed. Han ved, at ordene ligger der, og han kan hente dem efter forgodtbefindende. Dermed har han som den eneste magt over kanalen mellem oververden og underverden. 
Han kan bestemme over adgangen til den viden, der ligger i det nederste niveau, som han gør det ved at tilbageholde den sidste sang i Hávamál. Idet underverdenen hænger sammen med det ubevidste, inkluderer hans magt også adgangen til det ubevidste. Hermed forbinder han de to niveauer i psyken og skaber en helhed i sig, der rummer alle elementer i både kosmos og den enkeltes psyke. ${ }^{8}$

At Odin forbinder det bevidste og det ubevidste kan være en af grundene til, at han delvis dæmoniseres. Udover at være visdommens og skjaldenes gud er han også gud for magi, krig, sejr og død, dvs. for en lang række uforståelige og uforudsigelige ting, og dermed inkluderer hans domæne alt det mest angstfremkaldende i livet. Idet Odin har magt over kanalen mellem de to niveauer i cirklen, dæmoniseres han, fordi de ting, han henter fra underverdenen, bringer elementer af kaos med op i den ordnede oververden, dvs. i den ordnede bevidsthed. Dette kaos kan opfattes som en besættelse, idet det opleves som væsensfremmed for bevidstheden:

... during the process of gaining access to the contents of the unconscious, the conscious mind is overpowered and negated, producing a state of possession, during which the individual is at the mercy of the unconscious. (Auld 1976, 158)

Besættelsen knytter sig til magien, men også i høj grad til rusen. Rusen overvælder også bevidstheden og giver plads for inspiration fra alle niveauer af verden. Dermed er rusen til dels dæmonisk, men den rummer samtidig så mange vigtige elementer i forbindelse med evnen til at formulere sig, at dens positive egenskaber overskygger de angstfremkaldende.

Odin har kontrollen over kanalen, og en af hans opgaver bliver derfor at mediere mellem de to niveauer. Den medierende funktion varetager han først og fremmest ved at integrere elementer fra underverdenen i oververdenen. Han gør det med runerne og med mjøden. Mjøden er nok det bedste eksempel på den medierende funktion, idet Odin, efter at have bragt den op til oververdenen i én stor portion, deler ud af den i små mængder. I begrænsningen kontrolleres inspirationens ekstase, så den ikke kommer ud af kontrol, men tværtimod tjener til at forbinde de forskellige erfaringsniveauer og at give plads for den viden, underverdenen rummer.

Alt dette sker ved at give underverdenen og det ubevidste ord. Ordene former erfaringerne fra underverdenen og gør dem håndterlige. Det, der før var en passiv kraft, bliver gennem formuleringen til en aktiv og produktiv kraft, der kan benyttes kulturelt, dvs. til ordning af samfundet gennem kommunikation. Da først ordene via Odin er kommet ind i verden, bliver de i deres tilgængelighed et brugbart redskab for enhver.

Gennem ordet som kulturel kraft får myten omkring mjødens opståen igen betydning. Den skabtes, ifølge Snorri, i forbindelse med fredsslutningen mellem aser og vaner, den fredsslutning, der kan læses som samfundets opståen. For at kunne skabe et samfund, må man kunne tale sammen for gennem samtalen at kunne definere og ordne

\footnotetext{
${ }^{8}$ I forbindelse med læsningen af oververden og underverden som to aspekter af psyken, det bevidste og det ubevidste, hentes inspiration fra Auld 1976.
} 
samfundets institutioner. Et samfund kræver en vis form for ordning gennem fælles regler, og disse regler skal man både kunne tale sig til rette om og også kunne videregive til udefrakommende og til følgende generationer. Derfor er det vigtigt, at aser og vaner ved fredsslutningen gennem deres spyt ved fælles indsats skaber et fælles sprog. At aserne derefter opnår den fulde rådighed over mjøden og dermed magten til at definere samfundets orden, hvorigennem de skaber en ubalance i samfundet mellem de to grupper, er en anden problematik.

\section{Litteratur}

ADAM AF BREMEN

1978 Beskrivelse af øerne i norden. Oversat og kommenteret af Allan A. Lund, Århus.

AULD, RICHARD

1976 “The Psychological and Mythic Unity of the God Odin”, Numen 23, 145-160.

BACKHAUSEN, KiRSTEN

1999 Det frugtbare Ord - Om Odin og Ordet i den Norrøne Mytologi, Hovedfagsspeciale, Aarhus Universitet, Institut for Nordisk Sprog og Litteratur.

BOER, A.C.

(u. år og sted) Die Edda, Zweiter Band, Commentar.

Evans, DAviD A.H., ed.

1986 Hávamál, London.

FLECK, JERE

1971 “Odin’s Self-Sacrifice - A New Interpretation” I \& II, Scandinavian Studies 43, 119-142 og 385-413.

FRANK, ROBERTA

1981 "Snorri and the Mead of Poetry”, Ursula Dronke et al., eds., Speculum Norroenum, Odense, 155-170.

JÓNSSON, FINNUR

1924 Hávamál. Tolket af Finnur Jónsson, København.

LAKOFF, GEORGE \& MARK JOHNSON

1980 Metaphors We Live By, Chicago.

LEXICON POETICUM.

1966 Oprindelig forfattet af Sveinbjörn Egilsson, forøget og genudgivet af Finnur Jónsson, København.

NECKEL \& KUHN

1962 Edda, die Lieder des Codex Regius nebst verwandten Denkmälern. I. Text. Vierte, umgearbeitete Auflage, Heidelberg.

ROESDAHL, ELSE

1983 “Fra Vikingegrav til Valhal i 900-årenes Danmark”, Torben Kisbye \& Else Roesdahl, eds., Beretning fra andet tværfaglige vikingesymposium, Århus, 39-49.

Ross, MARgaRET CLUNIES

1994 Prolonged Echoes, Vol. 1: The Myths, Odense.

SCHJøDT, JENs PETER

1983 “Livsdrik og vidensdrik. Et problemkompleks i nordisk mytologi”, Religionsvidenskabeligt Tidsskrift 2, 85-102.

1988 “The 'fire ordeal' in the Grímnismál - initiation or annihilation?”, Mediaeval Scandinavia $12,29-43$.

1995 “Odin på træet. Initiation eller ofring”, Religionsvidenskabeligt Tidsskrift 27, 5-20. 
SEE, KLAUS VON

1972 Die Gestalt der Hávamál, Eine Studie zur eddischen Spruchdichtung, Frankfurt a.M.

SNORRI STURLUSON

1926 Edda, Finnur Jónsson, ed., København.

STEPHENS, JOHN

1972 “The Mead of Poetry: Myth and Metaphor”, Neophilogus 56, 259-268.

VRIES, JAN DE

1970 Altgermanische Religionsgeschichte, Band I, Berlin.

\section{Summary}

The Norse god Odin reigns over wisdom and poetry and thereby over language itself. Wisdom and language are joined together in the mead of poetry and several myths are concerned with the way Odin gains access to the mead. Mead is an intoxicating drink but the intoxication is first and foremost leading to a higher state of consciousness. The mead of poetry undergoes several transformations before it can be put to use, and linked to these transformations is the whole complex of death, rebirth and initiation. Mead and wisdom are drawn from the underworld and then symbolically reborn in the upper world, either through the mouth of Odin or by Odin undergoing a rite of initiation where he himself is reborn. Odin travels between the realms of the world and while travelling he brings mead, runes and wisdom from the underworld to the upper world. All these are connected to the word, and by supplying wisdom as well as the words to use in order to grasp that wisdom, he makes sure that the wisdom can be put to constructive use. By putting experiences into words you obtain a conscious understanding of their meanings and thereby an ability to act upon the obtained knowledge. With the words Odin opens a channel between the two realms of the world, but he keeps a few words and magic chants to himself. Thereby he remains the master of the channel and makes sure that the two realms do not collapse into one with chaos as the result.

\section{Kirsten Backhausen}

Stud.mag.

V. Stuckenbergsvej 23, 2.mf.

8210 Århus V 